\title{
Cow Urine: A Plant Growth Enhancer, Bio Fertilizer, Pesticide and Antifungal Agent
}

\author{
Bakang Kedumetse Kgasudi* and Modiri Mantswe
}

M.Sc Vegetable Science, Diploma in Animal Health, India

*Corresponding author

\section{Keywords}

Cow urine, Fungi, Chemicals, Bio fertilizer, Pesticide

Article Info

\section{Accepted:}

08 January 2020

Available Online:

10 February 2020

\section{A B S T R A C T}

A cow has high socio-cultural values, plays significant role in rural economy, represent cattle wealth and bio-diversity. Cow urine is the most effective substance of animal origin with innumerable therapeutic values. Various kinds of pathogens such as bacteria, fungi, viruses, nematodes, and mycoplasma causing diseases remain a major threat to public health, despite tremendous progress in human medicine. Many researches have been done and have shown cow urine use for treatment of skin diseases, stomach diseases, diabetes, etc. It is also useful in agriculture for preparation of vermicompost, biofertilizers and bio pesticides. It plays a significant role in production of vegetables and control of plant diseases. Researches on cow urine are summarized in this article. However, more well-planned researches are required to prove its qualities and benefits in agricultural production as well as medicinal importance in Botswana. Public awareness is also required to share knowledge and promote the importance and wide applications of cow urine.

\section{Introduction}

Infectious diseases caused by various kinds of pathogens such as bacteria, fungi, viruses, nematodes, and mycoplasma remain a major threat to public health, despite tremendous progress in human medicine. Their impact is particularly great in developing countries because of the relative unavailability of medicines and the emergence of widespread drug resistance (Kekuda et al., 2010). Among these, fungi are considered as most aggressive pathogens causing qualitative and quantitative damage on agricultural crops production. Fungal pathogens, namely, Fusarium oxysporum, Rhizoctonia solani, and Sclerotium rolfsii, are associated with damping off and wilting of most of vegetable crops (Sharma et al., (2016).

The plant diseases have significant role in crop production in terms of yield reduction 
and loss in production costs. One of the most widely used strategies to control plant diseases is the use of chemical agents. However, overuse and abuse of these chemical agents resulted in certain hazardous effects. These chemicals suffer from drawbacks such as high cost, toxicity to nontarget organisms, residual problem and development of resistance in pathogens. This situation triggered interest in searching alternatives for disease control. Natural products in particular from plants can be the potential candidates which can be used against phytopathogenic fungi. The use of these agents is risk-free when compared to synthetic chemicals.

One of the best methods to control plant diseases is organic farming, which is the form of agriculture that relies on techniques such as crop rotation, green manure, compost, and bio fertilizers which helps to maintain soil productivity. Organic farming excludes or strictly limits the use of chemical fertilizers, pesticides (herbicide, insecticides and fungicides), plant growth regulators, livestock feed additives, antibiotics and genetically modified organisms. Thus, the importance of organic sources of nutrients has been recognized in order to get higher yield without disturbing soil health and microorganisms. The use of organic sources of nutrients like cow urine in crop production is very crucial for assurance of food security on sustainable basis, which in turn not only improve the soil fertility for sustained crop productivity but also reduce the cost of inorganic fertilizers.

\section{Uses of cow urine}

In different research and studies conducted in India, it has been found out that cow urine play a significant role in production of vegetables and control of diseases. From time immemorial, India has been an agrarian country and the cow has been the backbone of their agriculture. Cow (Bos taurus) represents the vedic values of selfness service, strength, dignity and non-violence. Cow occupies the highest place of honor in Botswana civilization. When fertilizers and tractors were unknown, a cow was a mode of transport and the only source sustaining the entire agriculture and the lifestyle of many Batswana. During the last several decades, especially after green revolution the use of chemical fertilizers, pesticides and tractors have dealt a severe blow to the importance of a cows in the society.

The products of cow; dung, milk and leather are used for different purposes. In a cow based economy milk is the major resource where it is used for drinking, for making curd, cheese and other milk products. Cow dung was used in the olden days as a building material for houses and home decorations. Leather is mostly used to make traditional blankets, clothes and shoes. Cow urine ingredients are capable of treating many diseases as it has several medicinal properties and it is the best remedy to cure fungal and bacterial diseases.

In ancient medical practices cow urine was greatly used for its pharmacological importance like drinking it after one has been bitten by a poisonous snake. Cow urine contains many beneficial elements, that is, chemical properties, potentialities and constituents which help in removing all the ill effects and imbalances of the body caused by infectious agents. The powerful practice of healing "Self-urine therapy" has been referred in "Shivambukalpa Vidhi" part of 5000 years old document called Dammar Tantra linking this practice to Vedas, the sacred Hindu texts. Reference of urine therapy is also found in almost all the volumes of Ayurvedic literature and in one of the volume of Bhavaprakasha urine is termed as "Vishaghna" (anti 
Poisonous) killer of all poisons and "Rasayan" (Rejuvenative) which can rejuvenate even old person and purify blood and cures all skin diseases (Harshadet al., 2017). Cow urine destroys the diseases that are caused by poison (toxin). Various poisonous chemicals can be purified with the help of cow urine as well as increasing the immunity power by increasing resistance power against diseases in human body.

\section{Composition of cow urine}

It contains nitrogen, sulphur, phosphate, sodium, manganese, iron, silicon, chlorine, magnesium, maleic, citric, tartaric and calcium salts, vitamin A, B, C, D, E, minerals, lactose, enzymes, creatinine, hormones and gold acids. Ingredients of cow urine are similar with human body. Hence consumption of cow urine is useful to maintain the balance of these substances and cures incurable diseases.

Medicinal Properties of cow urine has been granted by US, as Patents (No. 6,896,907 and 6,410,059); bio enhancer, antibiotic, antifungal, and anticancer agent properties are particularly mentioned in those patents. Cow urine increases potency of "Taxol" (paclitaxel) against MCF-7, a human breast cancer cell line, in in vitro assays (US Patent No. 6,410,059) (Harshad et al., 2017).

Cow urine contains $95 \%$ water, $2.5 \%$ urea, and the remaining $2.5 \%$ a mixture of salts, hormones, enzymes, and minerals (Ramani, et al., 2012).

Healthy cow urine has volume of 17-45 $\mathrm{ml} / \mathrm{Kg} /$ day with specific gravity ranging from 1.025- 1.045. Its $\mathrm{pH}$ ranges between 7.4 to 8.4 with seasonal variations. Urea nitrogen and total nitrogen varies between $23-28 \mathrm{ml} / \mathrm{kg} /$ day and 40-45 $\mathrm{ml} / \mathrm{kg} /$ day respectively. Other important constituents are given below.
Ammonia nitrogen
$1-1.7 \mathrm{ml} / \mathrm{kg} /$ day
Allantoin
$20-60 \mathrm{ml} / \mathrm{kg} /$ day
Calcium
$0.1-1.4 \mathrm{ml} / \mathrm{kg} /$ day
Chloride
$0.1-1.1 \mathrm{mmol} / \mathrm{kg} /$ day
Creatinine
$15-20 \mathrm{mg} / \mathrm{kg} /$ day
Magnesium
$3.7 \mathrm{mg} / \mathrm{kg} /$ day
Potassium
$0.08-0.15 \mathrm{mmol} / \mathrm{kg} / \mathrm{day}$
Sodium
$0.2-1.1 \mathrm{mmol} / \mathrm{kg} / \mathrm{day}$
Sulphate
Uric acid
Leucocyte
$3-5 \mathrm{mg} / \mathrm{kg} /$ day
$1-4 \mathrm{mg} / \mathrm{kg} /$ day
$<15$ micro It

Urea is a strong antimicrobial agent and it is an end protein metabolism, while uric acid has antimicrobial activity and it helps to control infections. Iron is responsible for producing RBC while sodium and potassium plays major role as body electrolyte. Creatinine acts as an antibacterial (Harshad et al., 2017). It has been considered that cow urine is very useful in agricultural operations as a bio fertilizer (Dharma, 2005)and bio pesticide. Cow urine in combination with plant extracts is used to prepare disinfectant which is biodegradable and eco-friendly with good antibacterial action. Such bio pesticides do not have the harmful effects like chemical pesticides (Rekha et al., 2017, Ambika and Balakrishnan, 2015).

Cow urine is a rich source of macro, micronutrients and has disinfectant, prophylactic properties thus purify the atmosphere and improves soil fertility. Therefore it is an effective tool to address multi nutrient deficiencies in most of the soils and helps to provides nutrients to plants at low cost. Hence, it should be considered as an alternative source for plant nutrition, metabolic activation and pest disease control (Ambika and Balakrishnan, 2015).

Cow urine provides better alternative to synthetic chemicals which are expensive and pose potential danger to the farmers, marketers, consumers, and environment. With so many benefits of cow urine that is; the 
ability to enrich the soil, soil fertility and soil productivity. It changes soil texture, possess high amount of oxygen and nitrogen content which is used for production of superior quality compost to increase agricultural yield and save human beings from the residual effects of harmful pesticides and fertilizers. Cow urine acts as an antimicrobial agent. It balances micronutrients deficiencies in plants. When plants are sprayed with cow urine, foliage appears dark green hence helps in performing photosynthesis efficiently. It provides good environment in the soil for beneficial living microorganisms and useful earthworms. It acts as a natural insecticides and growth promoters in plants. Cow urine reduces the cost of cultivation and increases the cost of production. It has amazing germicidal power to kill varieties of germs. Cow urine helps in seed treatment for good germination and is used in various bioformulations.

Considering the scope of growth behaviour of different crops under different studies, showing promising results and a better way of organic farming that contributes more to soil health. However, the effects of cow urine in agricultural crops have not been studied so far in Botswana. Hence the objective of the present paper is to highlight the effects of cow urine on yield, growth, quality parameters and economics of different crops and its medicinal importance in human beings.

In conclusion, cow urine is an important organic source of nutrients for improving growth, yield and quality of many crops. Botswana is affected by climate change so organic sources of nutrients in crop production is very crucial for assurance of food security, sustainability and improving soil health thus minimising the use of chemicals in the soil. Cow urine has been found to be cost effective, with minimum adverse reaction when compare to modern medicine. An integrated approach is necessary to promote the highly valuable virtues and wide applications of cow urine. However, more well-planned researches are required to prove its qualities and benefits in agricultural production as well as medical in Botswana. Public awareness is also required to share knowledge and promote the importance and wide applications of cow urine.

\section{References}

Ambika, S. and Balakrishnan, K .2015. Enhancing germination and seedling vigour in cluster by organicpriming. Academic Journal. 10(8):298-301.

Dharma, K, Rajesh. R, Chauhan, R. S. and TomarSimmi. 2005. Panchgavya (cowpathy): An Overview. International Journal of Cow Science, 1(1): 1-15.

Harshad. G, Amit. N, Nilesh. M, Sunanda. B. andAmrut. S.2017. Gomutra (Cow urine): A multidimensional drug review article. International Journal Research. Ayurveda Pharm. 8(5):1-6

Kekuda, T. R. P, Nishanth, B.C, Kumar, S. V .P, Kamal D, Sandeep, M, Megharaj, H. K. 2010. Cow urine concentrate: a potent agent with antimicrobial and anthelmintic activity. Journal of Pharmacy Research. 3(5):1025-1027

Ramani, H. R, Garaniya, N.H. and Golakiaya, B. A. 2012. Biochemical constitutes of calf, pregnant and milking of cow urines at weekly intervals. A Journal of diary science and technology. 1(2):1-6.

Rekha. S, Lalchand, Rakshapal. G. and OmPrakash. R. 2017. Benefits of cow urine - a review. International Journal of Recent Advances in Multidisciplinary Research. 4(9):2833-2835.

Sharma, R, Shah, S. C, Adhikar, K. R, Shah, P. and Shrestha, J. 2016. Effects of cattle urine and farm yard manure on yield of broccoli and soil properties. Journal of Agriculture Search. 3(3): 157-160. 


\section{How to cite this article:}

Bakang Kedumetse Kgasudi and Modiri Mantswe. 2020. Cow Urine: A Plant Growth Enhancer, Bio Fertilizer, Pesticide and Antifungal Agent. Int.J.Curr.Microbiol.App.Sci. 9(02): 1294-1298. doi: https://doi.org/10.20546/ijcmas.2020.902.152 